\title{
Pengaruh tingkat partisipasi angkatan kerja, indeks harga konsumen, produk domestik regional bruto terhadap upah rata- rata Pulau Sumatera
}

\author{
Dearni Christina Purba; Purwaka Hari Prihanto; Siti Aminah
}

Prodi Ekonomi Pembangunan, Fakultas Ekonomi dan Bisnis, Universitas Jambi

E-mail korespodensi : purbadecepe@gmail.com

\begin{abstract}
This study ains to analyze the Development of Labor Force Participation Rate, Consumer Price Index and Gross Regional Domestic Product and Average Wages in Sumatera and analyze the influence of the Development of Labor Force Participation Rate, Consumer Price Index, and Gross Regional Domestic Product on Average Wages in Sumatera. The data used in this study are secondary data sourced from the Central Statistics Indonesia office. For data analysis using panel data analysis. The average wage is a Bound variable that is influenced by three independent variables, namely the Labor Force Participation Rate, the Consumer Price Index, and the Gross Regional Domestic Product. Based on the result of the analysis it is known that the Labor Force Participation Rate has a negative and not significant effect on the average wage in Sumatera. The consumer Price Index has a negative and not significant effect on the average wages in Sumatera. Gross Regional Domestic Product has a positive and significant effect on Average Wages in Sumatera.
\end{abstract}

Keywords: Labor force participation rate, Consumer price index, Gross regional domestic product, Average wages.

\begin{abstract}
Abstrak
Penelitian ini bertujuan untuk menganalisis Perkembangan tingkat partisipasi angkatan kerja, indeks harga konsumen, dan produk domestik regional bruto dan upah rata-rata pulau sumatera serta menganalisis pengaruh perkembangan tingkat partisipasi angkatan kerja, indeks harga konsumen, dan produk domestik regional bruto terhadap upah ratarata pulau sumatera. Data yang digunakan dalam penelitian ini adalah data sekunder yang bersumber dari kantor badan pusat statistik indonesia. Untuk analisis data menggunakan analisis data panel. Upah rata-rata adalah variabel terikat yang dipengaruhi oleh tiga variabel bebas yaitu tingkat partisipasi angkatan kerja, indeks harga konsumen, dan produk domestik regional bruto. Berdasarkan hasil analisis diketahui bahwa tingkat partisipasi angkatan kerja berpengaruh negatif dan tidak signifikan terhadap upah rata-rata pulau sumatera. Indeks harga konsumen berpengaruh negatif dan tidak signifikan terhadap upah rata-rata pulau sumatera. Produk domestik regional bruto berpengaruh positif dan signifikan terhadap upah rata-rata pulau sumatera.
\end{abstract}

Kata kunci: Tingkat partisipasi angkatan kerja, Indeks harga konsumen, Produk domestik regional bruto, Upah rata-rata . 


\section{PENDAHULUAN}

Upah menjadi salah satu persoalan yang selalu menjadi sorotan terutama di negara-negara berkembang seperti Indonesia. Hal ini mengingat bahwa upah merupakan komponen dari pendapatan seseorang sehingga tingkat upah merupakan salah satu indikator yang dapat mencerminkan kesejahteraan masyarakat dari suatu Negara. Salah satu upaya yang harus dilakukan adalah perlunya kajian kritis atas penghidupan buruh yang selama ini masih menjadi persoalan ketenagakerjaan di Indonesia, khususnya pemenuhan upah buruh yang dirasakan masih rendah (Bachtiar, 2008). Persoalan upah ini juga masih menjadi perhatian yang serius diantara banyak pihak seperti pekerja sebagai penerima upah, pengusaha sebagai pihak pembayar upah dan pemerintah sebagai regulator. Begitu pentingnya persoalan upah dalam hubungan ketenagakerjaan, maka kebijakan-kebijakan yang mengatur soal penguahan harus benar-benar mencerminkan kondisi pengupahan yang adil. Bagi pekerja atau pihak yang memberikan jasanya kepada pengusaha, upah merupakan penghasilan yang akan digunakan untuk memenuhi segala kebutuhan hidupnya dan keluarganya. Selain itu upah juga mempunyai arti sebagai motivasi kerja. Bekerja dengan mendapatkan upah merupakan status simbol pekerja dalam kedudukannya sebagai anggota masyarakat.

Upah diberikan sebagai bentuk balas jasa yang adil dan layak diberikan kepada para pekerja atas jasa-jasanya dalam mencapai tujuan organisasi. Upah dibayarkan kepada pekerja berdasarkan jam kerja, jumlah barang yang dihasilkan atau banyaknya pelayanan yang diberikan. Sedangkan menurut Mucharsyah sinungan, upah kerja adalah pencerminan pendapatan nasional dalam bentuk upah uang yang diterima oleh buruh sesuai dengan jumlah dan kualitas yang dicurahkan untuk pembuatan suatu produk. Selain pendapatan diatas, ada beberapa pengertian lain tentang upah, menurut Sadono sukirno, upah adalah pembayaran atas jasa-jasa fisik yang disediakan oleh tenaga kerja kepada para pengusaha.

Menurut Sumarsono dan Putu (2011) mengemukakan pula bahwa upah merupakan sumber utama penghasilan seseorang pekerja, sehingga upah haus cukup memenuhi kebutuhan pekerja dan keluarganya dengan wajar. Sedangkan bagi perusahaan, upah merupakan salah satu komponen biaya produksi yang dipandang dapat mengurangi tingkat laba yang dihasilkan. Sehingga pengusaha berusaha menekan upah tersebut sampai pada tingkat yang paling minimum. Oleh karena itu, laba perusahaan dapat ditingkatkan. Masih sedikit pengusaha yang memandang pekerja sebagai mitra perusahaan dala menjalankan dan menghasilkan keuntungan bagi perusahaan. Dipihak lain, karyawan atau ekerja menganggap upah sebagai balas jasa terhadap apa yang telah ia kerjakan, sehingga pekerjaan menuntut upah lebih untuk mencukupi kebutuhannya agar mereka dapat hidup sejahtera, tetapi dalam kenyataannya hanya sedikit pengusaha yang secara sadar dan sukarela untuk meningkatkan taraf hidup karyawannya, terutama pekerja golongan bawah.

Menurut BPS Nasional hasil survei upah buruh tahun 2018 secara nasional ratarata upah buruh tertinggi yaitu di provinsi Kepulauan riau yaitu sebesar Rp 2.409.760 per bulan, sedangkan rata-rata upah buruh terendah berada di provinsi Aceh dengan rata-rata upah sebesar Rp 1.853 .809 per bulan. Untuk provinsi Aceh, rata-rata upah diterima pekerja tergolong rendah, karena adanya angkanya berada dibawah rata-rata nasional. Kemudian jika dibandingkan dengan seluruh provinsi di Indonesia, rata-rata upah pekerja di provinsi Aceh berada pada urutan ke 21 tertinggi dari total provinsi di Indonesia. Kenaikan tingkat upah rata-rata akan mempengaruhi tingkat rendahnya biaya produksi perusahaan (Sumarsono, 2003). Kenaikan upah akan mengakibatkan peburunan kuantitas tenaga kerja yang diminta. Apabila tingkat upah rata-rata naik, 
maka harga tenaga kerja relatife lebih mahal dari input lain. Hal ini mendorong pengusaha untuk mengganti tenaga kerja yang relatif mahal dengan input-input lain yang harganya lebih murah guna mempertimbangkan keuntungan.

Berdasarkan data badan pusat statistik, tingkat partisipasi angkatan kerja (TPAK) meunjukkan selama tahun 2016 sampai tahun 2018 perkembangan TPAK pulau Sumatera mengalami fluktuasi. Dimana rata-rata perkembangan kenaikan TPAK pulau Sumatera sebesar 6,88 persen setiap tahunnya. Adapun jumlah TPAK tertinggi Pulau Sumatera yaitu pada tahun 2018 di provinsi Bengkulu mencapai 70,06 persen atau berkembang sebesar 0,76 persen. Selanjutnya pada tahun 2018, TPAK mengalami penurunan selama 3 tahun terakhir yaitu mencapai 0,50 persen. Sedangkan angka TPAK terkecil tercatat pada tahun 2018 yaitu sebesar 64,24 persen. Pada tahun 2018 jika dibandingkan dengan provinsi lain yang ada di pulau Sumatera, TPAK provinsi Jambi menempati peringkat ketiga terbesar di Pulau Sumatera. Setiap tindakan yang bermotif ekonomi, semua pihak yang terlibat didalam aktivitas tersebut, akan selalu berusaha untuk memaksimalkan manfaat sesuai dengan kepentingan masing-masing. Pekerja misalnya, akan berupaya untuk mendapatkan manfaat yang setinggi-tingginya dari interaksi kegiatan ekonomi mereka dengan berusaha seetinggi mungkin. Sedangkan pengusaha akan berupaya menekan biaya produksi se efisien mungkin yang dapat mereka lakukan untuk laba yang optimal, dimana menekan biaya kerja berupa penurunan upah( Bachtiar, 2008).

Berdasarkan data dari badan pusat statistik nasional, indeks harga konsumen menunjukkan selama tahun 2016 sampai dengan tahun 2018, perkembangan indeks harga konsumen pulau Sumatera mengalami fluktuasi. Dari ke 23 kota IHK pulau Sumatera pada bulan April 2018 mengalami inflasi. Inflasi tertinggi terjadi di kota Medan sebesar 1,30 peren dan terendah terjadi di kota Tanjung pinang sebesar 0,16 persen. Tolak ukur pertumbuhan ekonomi suatu negara dapat dilihat dari kemampuannya menghasilkan barang dan jasa. Salah satunya dapat dilihat dari pendapatan nasionalnya. Pendapatan nasionalnya adalah barang dan jasa yang dihasilkan oleh suatu negara dalam periode waktu tertentu biasanya satu tahun, perhitungan pendapatan nasional ini bertujuan untuk mendapatkan gambaran tentang tingkat ekonomi yang telah dicapai dan nilai output yang diproduksi (Sukirno, 2004).

Pulau sumatera apabila dilihat dari sisi produk domestik regional bruto memiliki potensi dibeberapa sektor yaitu sektor pertanian, industri pengolahan, perdagangan dan jasa. Dari sektor pertanian nilai terbesar berasal dari industry non migas, sedangkan dilihat dari sektor perdagangan, hotel dan restoran nilai terbesar berasal dari perdagangan besar dan eceren. Berdasarkan data dari badan pusat statistik nasional tahun 2010 diperoleh data PDRB tertinggi di pulau Sumatera pada provinsi Sumatera utara dengan nilai PDRB sebesar 111,18 milyar rupiah, sedangkan data PDRB terendah tahun 2010 di provinsi Bengkulu dengan nilai PDRB sebesar 30,295 milyar rupiah. Untuk data PDRB tertinggi 2016 di pulau Sumatera pada rovinsi Sumatera utara dengan nilai PDRB sebesar 463,151 milyar rupiah, sedangkan PDRB terendah tahun 2016 yaitu provinsi Bengkulu dengan nilai PDRB sebesar 40,002 milyar rupiah (BPS Indonesia, 2017). Adapun pertumbuhan ekonomi di pulau Sumatera sudah tinggi jika dibandingkan dari rata-rata pertumbuhan ekonomi di Indonesia. Hal ini berarti pemerintah gubernur pulau Sumatera sudah melakukan kebijakan yang baik dalam mengembangkan pertumbuhan ekonomi di pulau Sumatera. 


\section{METODE}

\section{Jenis dan sumber data}

Adapun jenis data yang digunakan dalam penelitian ini adalah analisa data sekunder. Jenis data sekunder yang digunakan adalah data panel yaitu gabungan antara data cross section dan data time series. Dimana data time series dimulai dari tahun 2016 - 2018 dan data cross section terdiri dari data 10 provinsi yang ada di pulau Sumatera. Data yang digunakan bersumber dari badan pusat statistik nasional.

\section{Metode analisis}

Metode analisis data yang digunakan dalam penelitian ini terdiri dari dua metode yaitu metode deskriptif dan metode kuantitatif. Penelitian ini tentang pengaruh tingkat partisipasi angkatan kerja, indeks harga konsumen, dan produk domestik regional bruto terhadap upah rata-rata pulau sumatera dapat di ilustrasikan dalam kerangka pemikiran berikut:

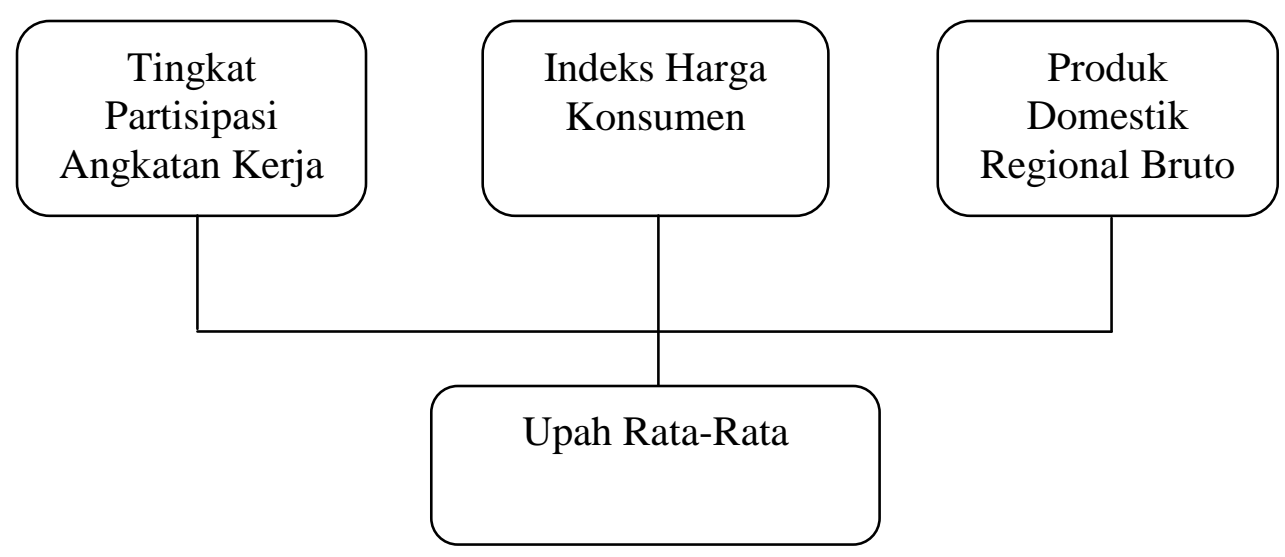

Gambar 1. Kerangka Pemikiran

Berdasarkan Gambar 1 dapat dibuat dua persamaan regresi yang menunjukkan hubungan yang dihipotesiskan, yaitu:

$$
\mathrm{URR}=\beta_{0}+\beta_{1} \operatorname{TPAK}_{i t}+\beta_{2} \mathrm{IHK}_{i t}+\beta_{3} \operatorname{InPDRB}{ }_{i t}+\varepsilon_{t}
$$

Keterangan :

$$
\begin{array}{ll}
\text { URR } & =\text { Upah Rata-rata } \\
\beta_{0} & =\text { Kontanta } \\
\beta_{1} \beta_{2} \beta_{3} & =\text { Koefisien Regresi Masing-masing variabel } \\
\text { TPAK } & =\text { Tingkat Partisipasi Angkatan Kerja } \\
\text { IHK } & =\text { Indeks Harga Konsumen } \\
\text { PDRB } & =\text { Produk Domestik Regional Bruto } \\
\varepsilon_{\mathrm{t}} & =\text { Error Ter }
\end{array}
$$

Teknik analisis data yang digunakan dalam penelitian ini adalah analisis linier berganda data panel yang menggunakan Eviews Versi 9.0 . Dari analisis diharapkan dapat digunakan bagaimana pengaruh yang dimiliki oleh setiap provinsi di pulau Sumatera dan untuk mengetahui seberapa besar pengaruh variabel terikat dengan variabel bebas.

\section{Operasional variabel}

Upah Rata-rata adalah upah upah rata-rata pulau Sumatera tahun 2016 sampai tahun 2018 dinyatakan dalam satuan rupiah. Tingkat partisipasi angkatan kerja yaitu jenis data 
yang digunakan dalam penelitian ini adalah data tingkat partisipasi angkatan kerja periode tahun 2016 sampai tahun 2018 yang dinyatakan dalam satuan persen. Indeks harga konsumen jenis data yang digunakan adalah data indeks harga kosumen periode tahun 2016 sampai tahun 2018. Produk domestik regional bruto adalah jumlah nila barang dan jasa yang dihasilkan dari seluruh kegiatan perekonomian daerah dalam satu tahun tertentu. Perhitungan PDRB dalam penelitian ini menggunakan harga kosntan tahun 2016 sampai tahun 2018 dalam satuan rupiah.

\section{HASIL DAN PEMBAHASAN}

Perkembangan tingkat partisipasi angkatan kerja, indeks harga konsumen, produk domestik regional bruto dan upah rata-rata pulau sumatera

Tingkat partisipasi angkatan kerja (TPAK) adalah suatu indikator ketenagakerjaan yang memberikan gambaran tentang penduduk yang aktif secara ekonomi dalam kegiatan sehari-hari merujuk pada suatu waktu dalam periode survei (Badan Pusat Statistik, 2014). Berikut ini dapat dilihat perkembangan tingkat partisipasi angkatan kerja pulau Sumatera pada periode 2016-2018:

Tabel 1. Perkembangan tingkat partisipasi angkatan kerja Provinsi-Provinsi di Pulau Sumatera Tahun 2016-2018

\begin{tabular}{lcccc}
\hline Provinsi & $\mathbf{2 0 1 6}$ & $\mathbf{2 0 1 7}$ & $\mathbf{2 0 1 8}$ & Rata-rata (2016-2018) \\
\hline Nanggroe Aceh Darussalam & 64,26 & 63,74 & 64,24 & 64,08 \\
Sumatera Barat & 65,99 & 68,88 & 71,82 & 68,89 \\
Sumatera Utara & 67,08 & 66,29 & 67,26 & 66,89 \\
Riau & 66,25 & 64,00 & 65,23 & 65,16 \\
Jambi & 67,54 & 67,52 & 68,46 & 67,84 \\
Sumatera Selatan & 71,59 & 69,50 & 68,69 & 69,92 \\
Bengkulu & 72,69 & 69,30 & 70,06 & 70,68 \\
Lampung & 69,61 & 67,83 & 69,67 & 69,03 \\
Bangka Belitung & 68,93 & 66,72 & 69,79 & 67,81 \\
Kepulauan Riau & 65,93 & 66,41 & 64,72 & 65,59
\end{tabular}

Sumber : BPS Provinsi Jambi, 2019(diolah)

Berdasarkan Tabel 1 dapat dilihat bahwa perkembangan tingkat partisipasi angkatan kerja selama tiga tahun terakhir di provinsi-provinsi pulau Sumatera mengalami fluktuasi. Dari uraian diatas dapat disimpulkan bahwa rata-rata perkembangan TPAK tertinggi terdapat pada provinsi Bengkulu dengan jumlah rata-rata 70,68 persen. Tingginya rata-rata TPAK provinsi Bengkulu dari provinsi lain dikarenakan upah minimum di provinsi Bengkulu masih lebih tinggi jika dibandingkan dengan provinsi lainnya. Sedangkan untuk rata-rata perkembangan TPAK terendah terdapat pada provinsi Nanggroe Aceh Darussalam sebesar 64,08 persen. Ini disebabkan oleh beberapa faktor salah satunya masih rendahnya jumlah penduduk yang ada di provinsi Nanggroe Aceh Darussalam.

\section{Perkembangan indeks harga konsumen}

Mankiw (2013), indeks harga konsumen adalah ukuran biaya keseluruhan barang dan jasa yang dibeli oleh konsumen. Ahli statistik pemerintah secara rutin menghitung 
dan melaporkan IHK. Berikut adalah perkembangan indeks harga konsumen pada Pulau Sumatera periode tahun 2016-2018 antara lain sebagai berikut:

Tabel 2. Perkembangan indeks harga konsumen Provinsi-Provinsi di Pulau Sumatera Tahun 2016-2018

\begin{tabular}{lcccc}
\hline Provinsi & $\mathbf{2 0 1 6}$ & $\mathbf{2 0 1 7}$ & $\mathbf{2 0 1 8}$ & Rata-rata (2016-2018) \\
\hline Nanggroe Aceh Darussalam & 119,94 & 125,83 & 128,20 & 124,65 \\
Sumatera Barat & 132,93 & 137,16 & 138,53 & 136,20 \\
Sumatera Utara & 133,48 & 136,30 & 139,77 & 145,51 \\
Riau & 127,95 & 127,95 & 136,54 & 130,81 \\
Jambi & 127,21 & 130,62 & 134,57 & 130,8 \\
Sumatera Selatan & 124,96 & 128,52 & 132,09 & 128,52 \\
Bengkulu & 135,03 & 139,84 & 143,13 & 139,19 \\
Lampung & 127,31 & 131,31 & 135,15 & 131,19 \\
Bangka Belitung & 133,40 & 133,40 & 141,67 & 136,15 \\
Kepulauan Riau & 126,01 & 130,26 & 133,34 & 129,87 \\
\hline
\end{tabular}

Sumber : BPS Provinsi Jambi, 2019 (diolah)

Berdasarkan Tabel 2 dapat dilihat bahwa perkembangan IHK selama tiga tahun terakhir di pulau Sumatera mengalami fluktuasi yang sangat ekstrim. Pada tahun 2018 untuk IHK terendah ditempati oleh provinsi Nanggroe Aceh Darussalam yang mana IHK hanya mencapai 124,65 dan jumah IHK tertinggi 145,51 ditempati oleh provinsi Sumatera Barat. Kenaikan IHK dapat menyebabkan peningkatan suku bunga, meningkatkan daya tarik mata uang dan kenaikan inflasi.

\section{Perkembangan produk domestik regional bruto}

Soebagyo(2007), PDRB pada hakikatnya menggambarkan tingkat kegiatan perekonomian suatu daerah baik yang dilakukan masyarakat, swasta maupun pemerintah dala suatu periode tertentu sehingga PDRB secara tidak langsung dapat digunakan sebagai indikator dalam menilai hasil kegiatan pembangunan ekonomi daerah secara keseluruhan dan berkelanjutan. Berikut adalah perkembangan produk domestik regional bruto pulau Sumatera sebagai berikut :

Tabel 3. Perkembangan produk domestik regional bruto Provinsi-Provinsi di Pulau Sumatera Tahun 2016-2018

\begin{tabular}{lcccc}
\hline Provinsi & $\mathbf{2 0 1 6}$ & $\mathbf{2 0 1 7}$ & $\mathbf{2 0 1 8}$ & $\begin{array}{c}\text { Rata-rata } \\
(\mathbf{2 0 1 6 - 2 0 1 8})\end{array}$ \\
\hline Nanggroe Aceh Darussalam & $111.374,30$ & $121.240,98$ & $126.824,49$ & $121.479,92$ \\
Sumatera Barat & $463.375,46$ & $407.531,23$ & $512.765,63$ & $461.224,10$ \\
Sumatera Utara & $148.134,24$ & $155.976,49$ & $163.995,27$ & $156.035,33$ \\
Riau & $458.769,34$ & $471.081,71$ & $482.087,22$ & $470.646,25$ \\
Jambi & $130.501,13$ & $136.556,71$ & $142.995,28$ & $136.684,37$ \\
Sumatera Selatan & $266.857,40$ & $281.571,01$ & $298.569,34$ & $282.323,58$ \\
Bengkulu & $40.076,54$ & $42.073,52$ & $44.171,16$ & $42.107,07$ \\
Lampung & $209.793,73$ & $220.625,57$ & $232.214,28$ & $220.877,86$ \\
Bangka Belitung & $47.848,37$ & $49.986,85$ & $52.212,09$ & $50.015,77$ \\
Kepulauan Riau & $162.853,04$ & $166.111,36$ & $173.689,13$ & $167.550,17$ \\
\hline
\end{tabular}

Sumber : BPS Provinsi Jambi, 2018 (diolah) 
Berdasarkan Tabel 3. data BPS (2018) menyatakan bahwa provinsi yang menglai perkembangan paling tinggi pada tahun 2018 adalah provinsi Riau Rp 470.646,25. Tingginya PDRB provinsi Riau dikarenakan dari sisi inflasi cukup stabil dengan 1,32 persen dan faktor lainnya seperti berkontribusi yakni penyelesaian proyek infrastruktur seperti jalan raya, jembatan dan irigasi terhadap pertumbuhan ekonomi.

\section{Perkembangan upah rata-rata Pulau Sumatera}

Menurut Sumarsono dan Putu (2011), mengemukakan bahwa upah merupakan sumber utama penghasilan seorang pekerja, sehingga upah harus cukup memenuhi kebutuhan pekerja dan keluarganya dengan wajar. Sedangkan bagi perusahaan, upah merupakan salah satu kompoen biaya produksi yang dipandang dapat mengurangi tingkat laba yang dihasilkan. Sehingga pengusaha berusaha menekan upah tersebut sampai pada tingkat laba yang paling minimum. Berikut adalah perkembaangan Upah rata-rata provinsi di pulau Sumatera antara lain sebagai berikut :

Tabel 4. Perkembangan upah rata-rata Provinsi di Pulau Sumatera Tahun 2016-2018

\begin{tabular}{lcccc}
\hline Provinsi & $\mathbf{2 0 1 6}$ & $\mathbf{2 0 1 7}$ & $\mathbf{2 0 1 8}$ & $\begin{array}{c}\text { Rata-rata } \\
(\mathbf{2 0 1 6 - 2 0 1 8})\end{array}$ \\
\hline Nanggroe Aceh Darussalam & $111.374,30$ & $121.240,98$ & $126.824,49$ & $121.479,92$ \\
Sumatera Barat & $463.375,46$ & $407.531,23$ & $512.765,63$ & $461.224,10$ \\
Sumatera Utara & $148.134,24$ & $155.976,49$ & $163.995,27$ & $156.035,33$ \\
Riau & $458.769,34$ & $471.081,71$ & $482.087,22$ & $470.646,25$ \\
Jambi & $130.501,13$ & $136.556,71$ & $142.995,28$ & $136.684,37$ \\
Sumatera Selatan & $266.857,40$ & $281.571,01$ & $298.569,34$ & $282.323,58$ \\
Bengkulu & $40.076,54$ & $42.073,52$ & $44.171,16$ & $42.107,07$ \\
Lampung & $209.793,73$ & $220.625,57$ & $232.214,28$ & $220.877,86$ \\
Bangka Belitung & $47.848,37$ & $49.986,85$ & $52.212,09$ & $50.015,77$ \\
Kepulauan Riau & $162.853,04$ & $166.111,36$ & $173.689,13$ & $167.550,17$
\end{tabular}

Sumber : BPS Pulau Sumatera, 2019 (diolah)

Berdasarkan Tabel 4 dapat dilihat perkembangan upah rata-rata provinsi di pulau Sumatera mengalami fluktuasi, sama halnya dengan TPAK, IHK dan PDRB. Provinsi yang mengalami perkembangan paling rendah pada tahun 2018 adalah provinsi Sumatera Selatan dengan jumlah Rp 2.065.091 dan provinsi yang paling mengalami perkembangan paling tinggi adalah provinsi Kepulauan Riau sebesar Rp 3.368.061.

\section{Hasil regresi}

Untuk menentukan model yang paling tepat digunakan dalam mengestimasi data panel, maka akan dilakukan pengujian pemilihan model dengan menggunakan Uji chow atau Likehood test ration dan Uji hausman.

\section{Uji chow untuk memilih antara model CE dan FEM}

Untuk mengetahui model manakah yang bagus antara model CE dan FEM ini, dapat dilakukan dengan melihat signifikansi probabilita dengan uji statistic $\mathrm{F}$. pengujian ini dikenal juga dengan Uji chow atau Likehood test ratio. Berikut ini adalah hasil yang diperoleh dengan menggunakan pengolah data Eviews 9.0 : 
Tabel 5. Hasil uji chow

Redundant Fixed Effects Tests

Pool: POOL

Test cross-section fixed effects

\begin{tabular}{lrrc} 
Effects Test & Statistic & d.f. & Prob. \\
Cross-section F & 7.814137 & $(9,17)$ & 0.0002 \\
Cross-section Chi-square & 49.093471 & 9 & 0.0000 \\
\hline
\end{tabular}

Sumber: Data diolah, 2019

Dari Tabel 5 tersebut memperlihatkan pengujian menggunakan Chow-Test atau Likehood Ratio, yaitu :

$\mathrm{H}_{0} \quad$ : mengikuti model CE

$\mathrm{H}_{1} \quad$ : mengikuti model FE

Output Eviews tersebut menunjukkan bahwa baik $\mathrm{F}$ test maupun chi-square signifikansi (p-value 0,0000 lebih kecil dari 10\%), sehingga $\mathrm{H}_{0}$ ditolak, maka model FEM lebih baik dibandingkan model CE.

\section{Uji hausman untuk memilih antara model FEM dan REM}

Untuk mengetahui model manakah yang bagus antara model FEM dan REM maka dilakukan uji hausman. Dengan mengikuti kriteria Wald, nilai statistik Hausman ini akan mengikuti distribusi Chi-square. Berikut ini hasil yang diperoleh dengan menggunakan Eviews 9.0 :

Tabel 6. Hasil uji hausman

Correlated Random Effects - Hausman Test

Pool: Untitled

Test cross-section random effects

Chi-Sq.

Test Summary Statistic Chi-Sq. d.f. Prob.

\begin{tabular}{llll} 
Cross-section random & 16.034881 & 3 & 0.0011 \\
\hline
\end{tabular}

Sumber: Data diolah, 2020

Berdasarkan Tabel tersebut menunjukkan pengujian hausman test yaitu:

$\mathrm{H}_{0} \quad$ : mengikuti Random Effect

$\mathrm{H}_{1} \quad$ : mengikuti model Fixed Effect

Output Eviews tersebut menunjukkan bahwa statistic chi-square memiliki p-value lebih kecil dibandingkan dengan $\alpha=0,1(0,0011<0,1)$, sehingga hipotesis $\mathrm{H}_{0}$ ditolak dan $\mathrm{H}_{1}$ diterima. Dengan demikian dapat disimpulkan bahwa model FEM lebih baik dibandingkan REM.

Berdasarkan uji estimasi data panel menggunakan tiga model yaitu Common Effect, Fixed Effect, dan Random Effect dan dilakukan pengujian pemilihan model dengan menggunakan uji chow atau likehood test ratio dan uji Hausman maka di dapatkan hasil terbaik menggunakan model Fixed Effect dengan menggunakan pengolah data Eviews 9.0. dengan menggunakan Fixed Effect model diperoleh hasil regresi data panel dengan persamaan sebagai berikut: 
Tabel 7. Hasil Fixed effect model

\begin{tabular}{crrrr}
\hline Variable & Coefficient & Std. Error & t-Statistic & Prob. \\
\hline C & -59464253 & 15329846 & -3.878986 & 0.0012 \\
TPAK? & -29.19114 & 37.35853 & -0.781378 & 0.4453 \\
IHK? & -18.90210 & 16.68404 & -1.132945 & 0.2730 \\
LOG(PDRB?) & 5820881. & 1451930. & 4.009065 & 0.0009 \\
Fixed Effects & & & \\
(Cross) & & & & \\
_ACEH-C & 31533310 & & & \\
_SUMBAR-C & 24523924 & & & \\
_SUMUT-C & -7518463. & & \\
_RIAU-C & -13859101 & & \\
_JAMBI-C & -6836636. & & & \\
_SUMSEL-C & -11138078 & & & \\
_BENGKULU-C & 272230.8 & & & \\
_LAMPUNG-C & -9643063. & & \\
_BABEL-C & -733799.6 & & \\
_KEPRI-C & -6600325. & & \\
\hline \hline
\end{tabular}

Cross-section fixed (dummy variables)

\begin{tabular}{lrll}
\hline \hline R-squared & 0.938159 & Mean dependent var & 2012404. \\
Adjusted R-squared & 0.894507 & S.D. dependent var & 1005600. \\
S.E. of regression & 326616.3 & Akaike info criterion & 28.52964 \\
Sum squared resid & $1.81 \mathrm{E}+12$ & Schwarz criterion & 29.13683 \\
Log likelihood & -414.9446 & Hannan-Quinn criter. & 28.72389 \\
F-statistic & 21.49156 & Durbin-Watson stat & 1.585161 \\
Prob(F-statistic) & 0.000000 & & \\
\hline
\end{tabular}

Sumber: Data diolah, 2020

Dari hasil regresi model Fixed Effect dapat dilihat konstanta Upah Rata-rata sebesar -59.4 dengan asumsi variabel indepeden (TPAK,IHK,PDRB) lainnya tidak ada. Nilai koefisien dari TPAK adalah sebesar -29.19114 menjelaskan bahwa jika nilai TPAK naik sebesar satu persen maka nilai Upah Rata-rata akan menurun sebesar -29.1 persen. Nilai koefisien dari IHK adalah sebesar -18.90210 menjelaskan bahwa jika nilai IHK naik sebesar 18.9 persen. Nilai koefisien dari PDRB adalah sebesar 5820881 menjelaskan bahwa jika nilai PDRB bertambah satu persen maka nilai Upah Rata-rata akan meningkat sebesar 58.2 persen.

\section{Uji simultan (Uji F)}

Pengujian variabel secara bersama-sama terhadap variabel terikat atau Upah Ratarata dilakukan dengan uji $F$. Dari perbandingan $F_{\text {hitung }}>F_{\text {Tabel }}$ maka dapat ditarik hipotesis $\mathrm{H}_{0}$ ditolak. Artinya variabel tingkat partisipasi angkatan kerja dan variabel indeks harga konsumen tidak mempunyai pengaruh yang signifikan terhadap upah ratarata. Dan variabel produk domestik regional bruto mempunyai pengaruh yang signifikan terhadap upah rata-rata di rovinsi-provinsi pulau Sumatera. 


\section{Uji parsial (Uji t)}

Uji-t digunakan untuk, enguji pengaruh individu dari variabel independen (TPAK,IHK, dan PDRB) terhadap variabel dependen (Upah Rata-rata). Pengujian statistik dilakukan dengan membandingkan antara nilai-t hitung dengan nilai t-Tabel pada $\alpha=0.1 \%$. dari hasil pengujian ini didapat bahwa nilai t-hitung nya $-0,78$ dengan probabilita sebesar 0,4453 atau lebih besar daripada alpha 0,1. Maka $\mathrm{H}_{0}$ diterima dan $\mathrm{H}_{\mathrm{a}}$. Dari hasil tersebut dapat disimpulkan bahwa variabel TPAK tidak memiliki pengaruh signifikan terhadap upah rata-rata. Variabel IHK dapat dilihat nilai t-hitung nya -1,78 dengan probabilita sebesar 0,2730 atau lebih besar daripada alpha 0,1 . Maka $\mathrm{H}_{0}$ diterima dan $\mathrm{H}_{\mathrm{a}}$ ditolak. Dari hasil tersebut dapat disimpulkan bahwa variabel IHK di Pulau Sumatera tidak memiliki pengaruh signifikan terhadap Upah Rata-rata. Variabel PDRB dapat dilihat bahwa nilai t-hitung nya 4.00 dengan probabilita sebesar 0.0009 atau lebih kecil daripada alpha 0,1 . Maka $\mathrm{H}_{0}$ ditolak dan $\mathrm{H}_{\mathrm{a}}$ diterima. Dari hasil tersebut dapat disimpulkan bahwa variabel PDRB berpengaruh dan signifikan terhadap upah rata-rata di pulau Sumatera.

\section{Koefisisen determinasi (R-Square)}

Dalam pengolahan data ini didapat nilai R-Squared sebesar 0.938159 artinya tingkat partisipasi angkatan kerja dan indeks harga konsumen tidak mempengaruhi nilai upah rata-rata di provinsi pulau Sumatera. Sedangkan variabel produk domestik regional bruto berpengaruh dan signifikan terhadap upah rata-rata di provinsi pulau Sumatera sebesar 93,8 persen. Dan 0,0072 dipengaruhi oleh faktor lain yang tidak digunakan dalam penelitian ini.

\section{Pengaruh tingkat partisipasi angkatan kerja terhadap upah rata-rata}

Berdasarkan hasil estimasi model Fixed Effect, menunjukkan bahwa nilai koefisien dari TPAK sebesar satu persen maka nilai Upah Rata-rata tidak meningkat dan tidak mempengaruhi sebesar -29.19114, menjelaskan bahwa jika TPAK naik sebesar satu persen maka nilai upah rata-rata sebesar -29,19 persen di provinsi-provinsi pulau Sumatera.

Variabel tingkat partisipasi angkatan kerja memiliki prob 0.445. lebih besar dibandingkan tingkat keyakinan $10 \% \quad(0,0000<0,1)$, artinya variabel tingkat partisipasi angkatan kerja tidak berpengaruh dan tidak signifikan terhadap upah ratarata di provinsi pulau Sumatera.

\section{Pengaruh indeks harga konsumen terhadap upah rata-rata}

Berdasarkan hasil estimasi model Fixed Effect menunjukkan bahwa nilai koefisien indeks harga konsumen sebesar 18.90210 menjelaskan bahwa jika IHK naik sebesar satu persen maka nilai upah rata-rata meningkat sebesar 18,9 persen di provinsi pulau Sumatera.

Variabel indeks harga konsumen memiliki prob 0.2730 lebih besar dibandingkan tingkat keyakinan $10 \%(0,0000<0,10)$, artinya variabel indeks harga konsumen tidak berpengaruh dan tidak signifikan terhadap upah rata-rata di provinsi pulau Sumatera.

\section{Pengaruh produk domestik regional bruto terhadap upah rata-rata}

Berdasarkan estimasi model Fixed Effect menunjukkan bahwa nilai koefisien produk domestik regional bruto sebesar 5820881 menjelaskan bahwa jika produk domestik regional bruto naik sebesar satu persen maka nilai upah rata-rata meningkat sebesar 58,2 persen di provinsi pulau Sumatera. 
Variabel produk domestik regional bruto memiliki prob. 0,0009 lebih kecil dibandingkan tingkat keyakinan $10 \%(0,0000<0,10)$, artinya variabel produk domestik regional bruto berpengaruh dan signifikan terhadap upah rata-rata di provinsi pulau Sumatera.

\section{KESIMPULAN DAN SARAN}

\section{Kesimpulan}

Bahwa perkembangan tingkat partisipasi angkatan kerja, indeks harga konsumen dan produk domestik regional bruto di pulau Sumatera mengalami fluktuasi disetiap tahunnya dalam periode penelitian. Rata-rata perkembangan upah rata-rata pada provinsi Aceh adalah sebesar 64,08 peren dan pada provinsi Sumatera Barat rata-rata perkembangan upah rata-rata adalah sebesar 68,89 persen. Rata-rata perkembangan upah rata-rata pada provinsi Sumatera Utara sebesar 66,89 persen lebih besar dibandingkan rata-rata perkembangan upah rata-rata pada provinsi Riau yaitu sebesae 66,16 persen. Pada provinsi Jambi rata-rata perkembangan upah rata-rata perkembangan upah rata-rata pada provinsi Sumatera Selatan yaitu sebesar 69,92 persen. Untuk ratarata perkembangan upah rata-rata pada provinsi Bengkulu adalah sebesar 70,68 persen jauh lebih besar dibandingkan rata-rata perkembangan upah rata-rata pada provinsi Lampung yaitu sebesar 69,03 persen. Rata-rata perkembangan upah rata-rata pada provinsi Bangka Belitung yaitu sebesar 67,81 persen lebih besar dibandingkan dengan rata-rata perkembangan upah rata-rata pada provinsi Kepulauan Riau yaitu sebesar 65,68 persen.

\section{Saran}

Berdasarkan penelitian ini, tingkat partisipasi angkatan kerja, tidak berpengaruh negatif dan tidak signifikan terhadap upah rata-rata di provinsi pulau Sumatera. Maka dari itu, pemerintah daerah harus tetap mendorong peningkatan upah rata-rata melalui peningkatan keterampilan dan keahlian, pendidikan maupun peningkatan efesiensi riset dan pengembangan teknoligi produktifitas tenaga kerja. Termasuk juga untuk indeks harga konsumen, dimana mampu mendorong laju pertumbuhan upah rata-rata. Kebijakan pemerintah dengan memberi fasilitas yang memadai, infrastruktur yang mendorong dan intensif bagi usaha atau industry yang tergolong kecil, sehingga upah rata-rata di Pulau sumatera dapat meningkat dengan baik. Sedangkan untuk produk domestik regional bruto dalam penelitian ini berpengaruh positif dan signifikan terhadap upah rata-rata di provinsi Pulau Sumatera. Kebijakan pemerintah dengan memberi fasilitas yang memadai, infrastruktur yang mendukung dan intensif bagi usaha atau industri yang tergolong kecil, sehingga PDRB di pulau Sumatera dapat meningkat dengan baik.

\section{DAFTAR PUSTAKA}

Bachtiar, Nasri .(2008). Permintaan Industri Manufaktur Terhadap Tenaga Kerja Mahir di Indonesia. Tesis. Sumatera Barat : Unversita Andalas: Padang

Badan Pusat Statistik Provinsi Jambi.(2018). Profil Tingkat Partisipasi Angkatan Kerja Pulau Sumatera 2018. Diakses dalam http://bps.go.id, pada Berita Resmi Statistik Tanggal 20 Agustus 2019, Pukul 15.00.

Badan Pusat Statistik Provinsi Jambi.(2018). Profil Indeks Harga Konsumen (IHK) Pulau Sumatera 2018. Diakses dalam http://bps.go.id, pada Berita Resmi Statistik Tanggal 20 Agustus 2019, Pukul 15.00. 
Badan Pusat Statistik Provinsi Jambi.(2018). Profil Produk Domestik Regional Bruto September 2018. Diakses dalam http://bps.go.id, pada Berita Resmi Statistik Tanggal 21 Agustus 2019, Pukul 19.00.

Badan Pusat Statistik Provinsi Jambi.(2019). Profil Upah Rata-rata Agustus 2019. Diakses dalam http://bps.go.id, pada Berita Resmi Statistik Tanggal 21Agustus 2019, Pukul 19.00.

Mankiw, Gregory.(2013). Pengantar Ekonomi Makro. Salemba Empat : Jakarta.

Sumarsono, Sony.(2003). Ekonomi Sumber Daya Manusia dan Ketenagakerjaan. Graha Ilmu : Yogyakarta.

Sumarsono \% Putu.(2011). Ekonomi Sumber Daya Manusia Teori dan Kebijakan Publik. Graha Ilmu : Yogyakarta.

Soebagyo, Daryono.(2017). Kasualitas Granser PDRB Terhadap Kesempatan Kerja di Provinsi Jawa Tengah. Jurnal Ilmu Ekonomi Terapan. 1(2), 17-33.

Sukirno, Sadono.(2004). Teori Pengantar Makro Ekonomi Edisi Ketiga: Jakarta. 